UNITED STATES DEPARTMENT OF THE INTERIOR GEOLOGICAL SURVEY

PETROLEUM POTENTIAL OF WILDERNESS LANDS, WYOMING

By Charles W. Spencer, and Richard B. Powers

MISCELLANEOUS INVESTIGATIONS SERIES

Published by the U.S..Geological Survey, 1983 


\section{Petroleum Potential of}

\section{Wilderness Lands in \\ Wyoming}

By Charles W. Spencer

With a section on The Wyoming part of the Wyoming-

Utah-Idaho Thrust Belt, by Richard B. Powers

PETROLEUM POTENTIAL OF WILDERNESS LANDS IN THE WESTERN UNITED STATES

GEOLOGICAL SURVEY CIRCULAR $902-M$

This chapter on the petroleum

geology and resource potential of

Wilderness Lands in Wyoming is

also provided as an accompanying

pamphlet for Miscellaneous Inves-

tigations Series Map I-1547 



\section{CONTENTS}

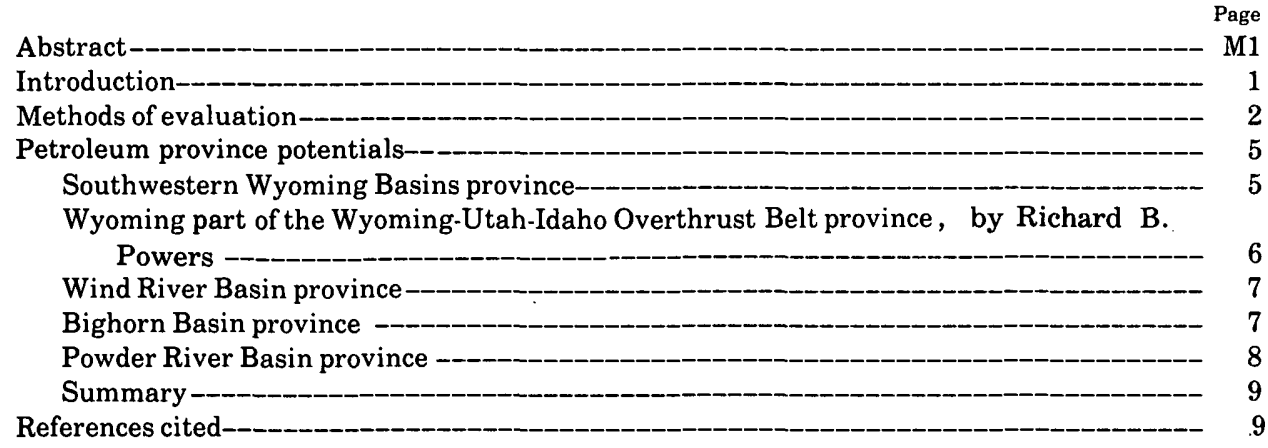

\section{ILLUSTRATIONS}

Figure 1. Map of Wyoming showing selected basins and uplifts, Wilderness Lands, and oil and gas potentials for the Wilderness Lands

2. Map of Wyoming showing USGS petroleum provinces (Dolton and others 1981, p. 75), Wilderness Lands, and the oil and gas potentials for the Wilderness Lands

3. Map of Wyoming showing location of Wilderness Lands and oil and gas fields - 


\title{
PETROLEUM POTENTIAL OF WILDERNESS LANDS IN THE WESTERN UNITED STATES
}

\section{Petroleum Potential of Wilderness Lands in Wyoming}

\author{
By Charles W. Spencer
}

\section{ABSTRACT}

A comprehensive review of the geology of 6,006,903 acres has been made to assess the petroleum potential of the Wilderness Lands in Wyoming. The potential for oil and gas accumulations in Wilderness Lands in Wyoming ranges from high to zero. Lands with high potential are located mostly within sedimentary basins where thick sequences of good reservoir rocks and hydrocarbon source beds are present. High potential tracts are also present in the Wyoming Thrust belt in western Wyoming. Areas with zero oil and gas potential are located mostly on mountain uplifts where Precambrian igneous and metamorphic rocks are exposed. A large portion of Yellowstone National Park lands has unknown potential owing to a thick cover of Tertiary and Quaternary volcanic and volcaniclastic rocks and sediments.

The petroleum potential for Wilderness Lands in Wyoming can be summarized by acreage as follows: high potential, 661.8 thousand acres; medium potential, 391.8 thousand acres; low potential, 723.3 thousand acres; low to zero potential, 19.0 thousand acres; zero potential, 1,759.3 thousand acres; and unknown potential, 2,451.8 thousand acres.

\section{INTRODUCTION}

An assessment has been made of the oil and gas potential of Wilderness Lands in Wyoming. The types of Wilderness Lands are shown on a map of Wyoming prepared by the U.S. Bureau of Land Management (1981). These Wyoming Wilderness Lands include: USFS Designated Wilderness, USFS and NPS Administratively Endorsed as Suitable (prior to 1981), BLM and USFS Further
Planning or Study Areas, and BLM Lands Under Appeal.

The tectonic elements of Wyoming and other Rocky Mountain States are identified and discussed by Grose (1972). The oil and gas map of Wyoming by VerPloeg and others (1980) shows a structure contour map of Wyoming. The general surface geology of the State is shown by Love and others (1955). The structure and stratigraphy of Wyoming and other Rocky Mountain States are discussed in Mallory (1972).

The State of Wyoming is a structurally complex area consisting of low to high mountain uplifts with adjacent basins. Selected uplifts and basins are shown in figure 1. Some of the major basins are the northern Denver basin in the southeast, the Powder River basin in the northeast, the Green River, Washakie, and Great Divide basins in the southwest, the Wind River basin in the west-central, and the Bighorn basin in the northwest part of the State. The Wyoming Thrust belt is present on the west and southwest margin of the State. As shown in figure 1, most of these large basins and other smaller basins are separated by major uplifts or arches. The cores of many of the uplifts are Precambrian igneous and metamorphic rocks. Some of the wilderness and wilderness study areas are located on exposed Precambrian rocks and therefore have zero oil and 

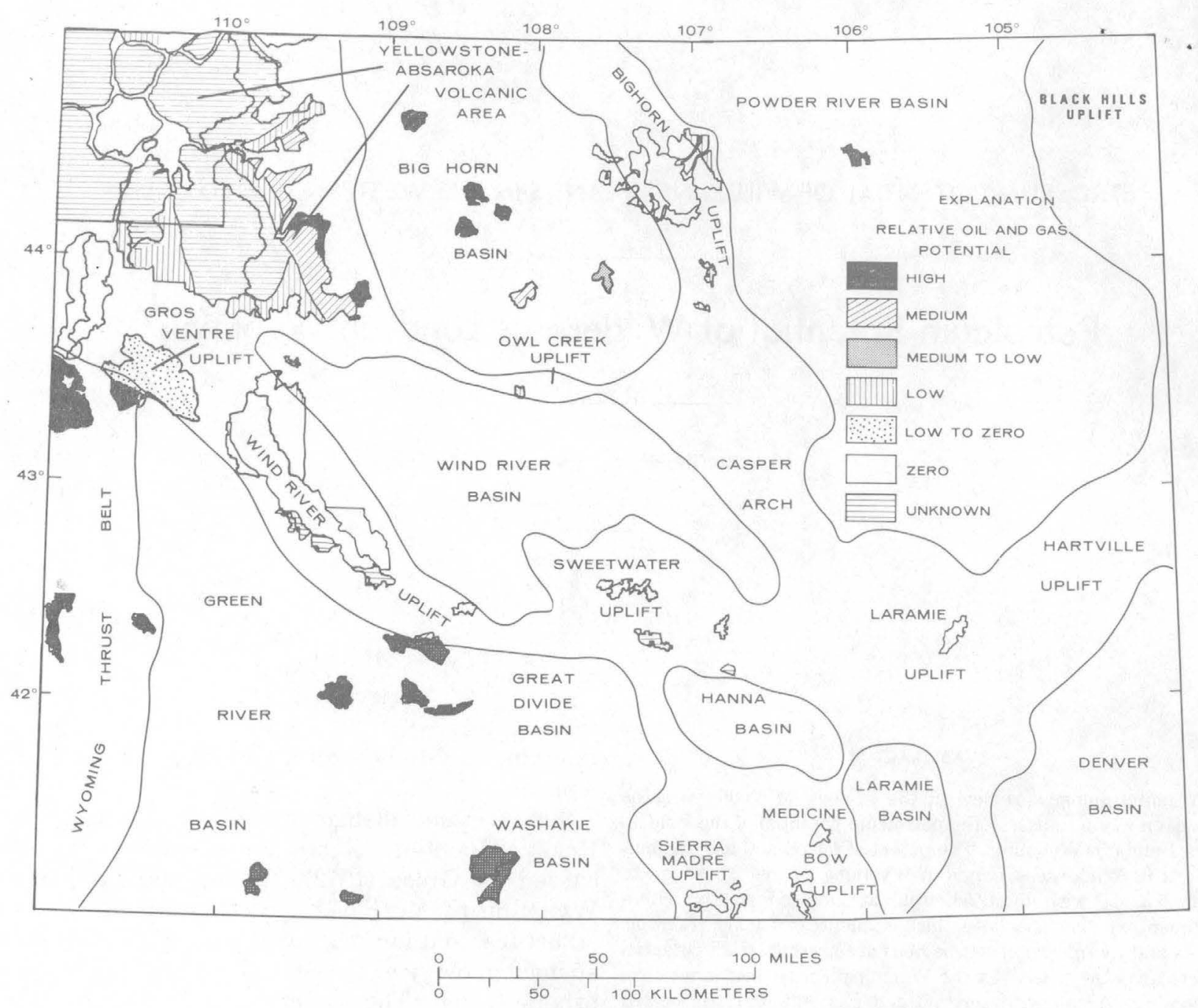

FIgURE 1.-Map of Wyoming showing selected basins and uplifts, Wilderness Lands, and the oil and gas potentials for the Wilderness Lands.

gas potential. However, in some Wyoming localities Precambrian rocks are thrust over prospective sediments; consequently, some Precambrian outcrop areas have oil and gas potential (Gries, 1983). The Yellowstone-Absaroka Tertiary and Quaternary volcanic area is present in the northwest corner of Wyoming.

Figure 1 shows the location and qualitative oil and gas potential of the Wilderness Lands in Wyoming and selected basins and uplifts. These boundaries are defined on geologic features and are slightly different from the USGS petroleum province boundaries shown in figure 2 which were used by Dolton and others (1981) and generally follow along county lines in Wyoming.

Through 1981, oil and gas fields in Wyoming had produced 4,944 million barrels of oil and 9,002 bil- lion cubic feet of gas (Wyoming Oil and Gas Conservation Commis., 1981). Most of the oil and gas was produced from reservoirs of Mississippian, Pennsylvanian, Permian, Triassic, Jurassic, Cretaceous, and Tertiary age. The location of Wyoming basins, oil and gas fields, and the age of producing formations are shown in VerPloeg and others (1980). Figure 3 is a map of Wyoming showing the location of oil and gas fields.

\section{METHODS OF EVALUATION}

This evaluation is based on both published and unpublished data and takes into consideration the distribution and types of oil and gas accumulations in both producing and abandoned fields. The analysis is primarily based on the known or interpre- 
ted distribution of reservoir rocks and hydrocarbon source beds, geologic history, and stratigraphic and structural style favorable for oil and gas accumulations in Wyoming and adjacent States.

Hydrocarbon accumulations require four critical factors: (1) reservoir (porous) rocks, (2) hydrocarbon (organic-rich) source beds, (3) a relatively impermeable seal or barrier to prevent upward and (or) lateral migration of hydrocarbons, and (4) favorable thermal history. It is a generally accepted fact that temperature and time are required to thermochemically alter organic material (kerogen) and yield oil and (or) gas. Shallow, lowtemperature gas of biologic origin is not believed to have any significant resource potential within any of the Wyoming Wilderness Lands.
Two main types of hydrocarbon traps exist: (1) structural traps, usually related to tectonic movement and include, but are not limited to, folds (anticlines) and faults or combinations of folds and faults; and (2) stratigraphic traps, those traps formed by an updip change of porous sandstone or carbonate into relatively impermeable rocks. In many fields the hydrocarbon trap is a combination of both structure and stratigraphy.

The relative ratings of hydrocarbon potential used in this evaluation are as follows:

High potential.-Geologic environment highly favorable for occurrence of oil and gas accurnulations. Area is within or on trend with existing production from structural and (or) stratigraphic traps.

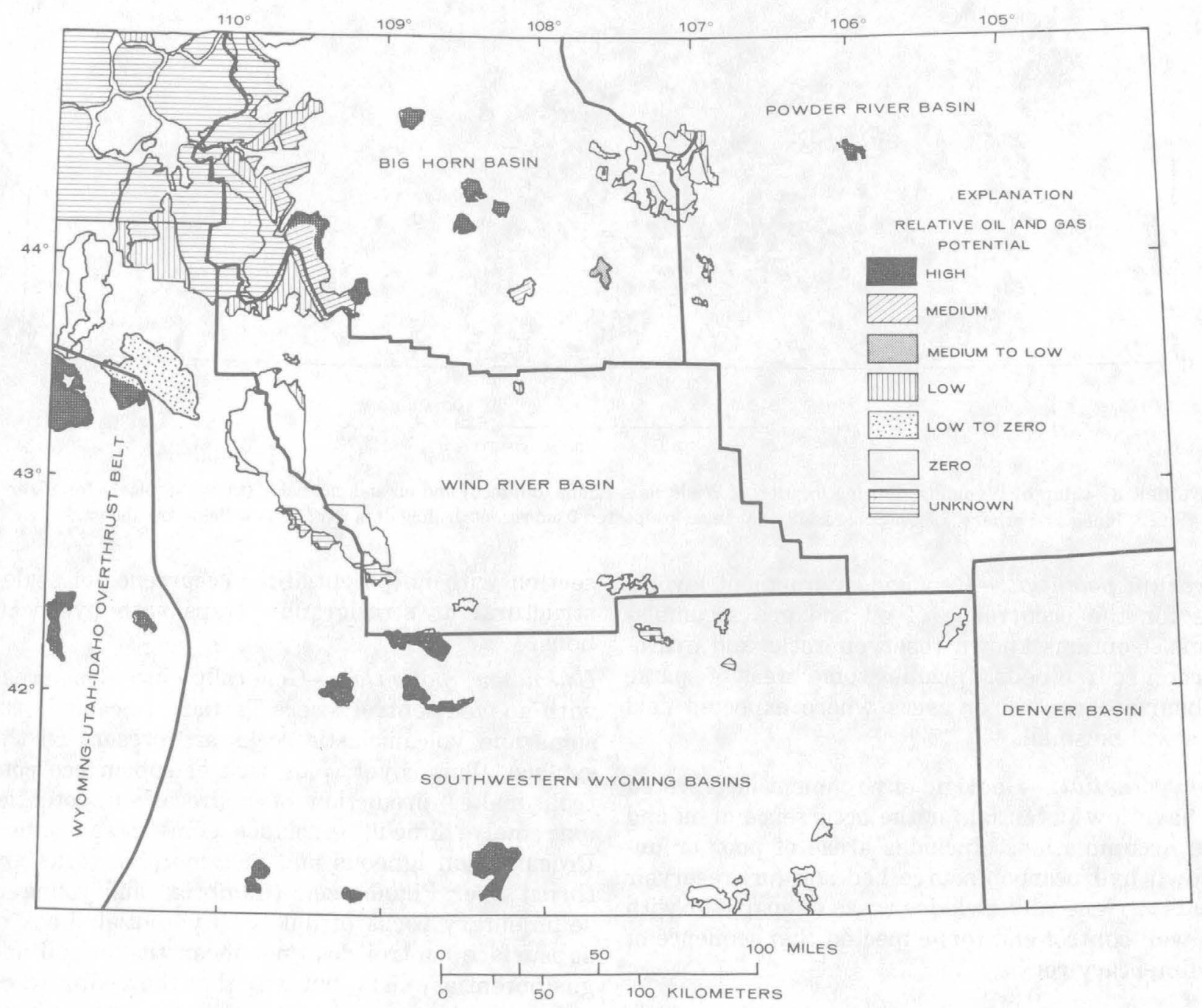

FIGURE 2.-Map of Wyoming showing USGS petroleum provinces (Dolton and others 1981, p. 75), Wilderness Lands, and the oil and gas potentials for the Wilderness Lands. 


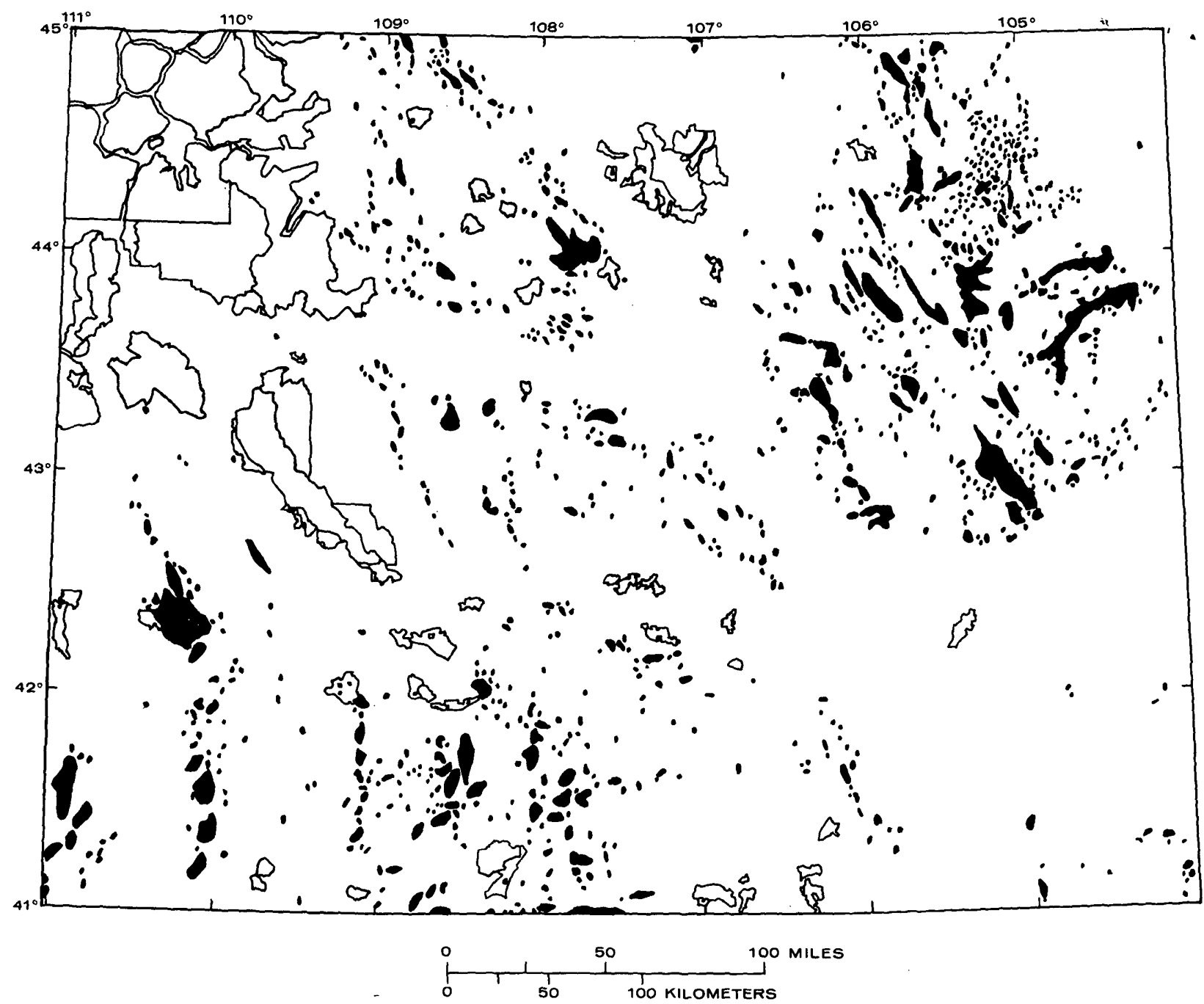

Figure 3.-Map of Wyoming showing location of Wilderness Lands (outlined) and oil and gas fields (shown in black) from VerPloeg and others (1980). Some additional fields are posted from recent drilling data. Not all new fields are shown.

Medium potential.-Geologic environment favorable for the occurrence of oil and gas accumulations. Contains known reservoir rocks and hydrocarbon source beds. Includes some areas of sparse subsurface control or areas where expected field size will be small.

Low potential.-Geologic environment interpreted to have low potential for the occurrence of oil and gas accumulations. Includes areas of poor or unknown hydrocarbon source bed and (or) reservoir quality. Generally includes areas of sparse or with no well control and (or) expected thin sequence of sedimentary rocks.

Zero potential.-Areas generally with exposed Precambrian rocks or with very thin sedimentary section with no potential for occurrence of sealed structural or stratigraphic traps with hydrocarbons.

Unknown potential.-Generally includes areas with no well control where Tertiary volcanic intrusions and volcaniclastic rocks are present on the surface. This cover, plus lack of subsurface control, makes prediction of hydrocarbon potential extremely difficult. Includes some areas where Precambrian igneous and metamorphic rocks are thrust over Phanerozoic (Cambrian and younger) sedimentary rocks of unknown potential. Lack of subsurface control does not mean that no oil and gas potential exists, but only that the hydrocarbon potential cannot reasonably be determined with present data. 


\section{$\therefore$ PETROleum PROVINCE POTENTIALS}

Figure 2 shows resource province names and boundaries as used in Dolton and others (1981). The boundaries of these provinces are placed mostly along county lines and do not exactly agree with the basins and uplifts shown in figure 1 which are placed along geologic boundaries.

\section{SOUTHWESTERN WYOMING BASINS PROVINCE}

The Southwestern Wyoming Basins province is a major oil and gas producing region. Skeeters and Hale (1972) summarized the petroleum geology of this province. Oil and gas are produced from both structural and stratigraphic traps. Cretaceous and Tertiary sandstones are the major producing reservoirs, but production has also been established from Cambrian sandstone, Mississippian carbonate rocks, Pennsylvanian carbonate rocks and sandstone, and Jurassic sandstone.

This province includes the Laramie, Medicine Bow, and Sierra Madre uplifts (fig. 1). Wilderness Lands on these uplifts are in areas of exposed Precambrian rocks and have zero oil and gas potential. However, unpublished data and data from Gries (1983) indicate that the Precambrian rocks along the west flank of the Sierra Madre uplift (fig. 1) are thrust an unknown distance westward and southwestward over Paleozoic and Triassic sedimentary rocks. This thrust, however, is not sufficiently defined to indicate that the Sierra Madre tracts have any potential.

Two tracts along the southwest flank of the Sweetwater (Granite Mountains) uplift (fig. 1) are shown as having unknown potential. The Emigrant Trail thrust bounds the southwest and west flank of the northwest part of this uplift (Gries, 1983). Wells drilled through the Emigrant Trail thrust have confirmed the presence of Precambrian rocks thrusted over Paleozoic and Mesozoic sedimentary rocks (Gries, 1983). This thrust trend probably continues southeastward and forms the north edge of the Hanna basin (Gries, 1983, fig. 1). The presence of sedimentary rocks with petroleum potential beneath the tracts rated as unknown cannot presently be determined. Other tracts on the Sweetwater uplift have zero potential because they are in areas of exposed Precambrian rocks which are probably not thrust over sedimentary rocks with petroleum potential.
The Greater Green River basin in Wyoming consists of three basins or subbasins: the Washakie basin, the Great Divide basin (Red Desert basin of oil industry usage), and the Green River basin proper. The Green River basin is bounded on the west by the Wyoming Thrust belt.

Tracts in the Green River basin proper have high potential for gas accumulations in stratigraphic and structural traps in Cretaceous sandstone. However, there is low potential for structurally controlled oil and gas accumulations in Jurassic sandstone and Permian and Pennsylvanian sandstones and carbonates. Tracts in the Washakie basin have high potential for gas in Cretaceous sandstone and low potential for oil in Paleozoic reservoirs. Tracts in the Great Divide basin have high potential for gas and some oil in stratigraphic traps in Cretaceous and Tertiary sandstone. A small portion of Bureau of Land Management tract 040-323 lies within the Wind River Basin province of Dolton and others (1981) and all of tract $040-325$ lies within the Wind River Basin province. Geologically these tracts are within the Great Divide basin. These tracts have high and medium potential for hydrocarbon accumulations in stratigraphic traps in front of and beneath the thrust that bounds the southwest flank of the Wind River uplift (Gries, 1983). The best potential is for gas accumulations in Cretaceous and Tertiary sandstone stratigraphic traps. To the northwest, a few tracts on the southwest flank of the Wind River uplift have unknown potential because the presence of potentially oil and gas productive rocks beneath the thrust cannot be determined. Most of the Wilderness Lands on the uplift have zero potential because they are in areas of exposed Precambrian rocks and (or) thin Paleozoic rocks that have not been thrust over sedimentary rocks with petroleum potential.

The Gros Ventre Wilderness area is located adjacent to the extreme northwest corner of the Green River basin (fig. 1) and is partly within the Wyoming Thrust belt. Simons and others (1980) studied the geology and mineral potential of the Gros Ventre Wilderness Study Area in considerable detail. They concluded that the southwest flank of the Gros Ventre Wilderness (uplift) is bounded by the Cache Creek thrust fault and that this thrust had moved from north and northeast to south and southwest and had overridden petroleum potential Paleozoic and Mesozoic rocks. They noted that hydrocarbon accumulations may be present in structural and stratigraphic traps in 
front of (southwest of) the Cache Creek thrust as well as in structural and stratigraphic traps beneath the thrust (Simons and others, 1980, p. 57). They also note that several wells in the area have reported oil and gas "shows." The area adjacent to and in front of the Cache Creek fault is rated in the present study as having high oil and gas potential. The area north and east of the fault, on the main part of the uplift, has some structurally high exposures of Precambrian and Cambrian rocks as well as extensive outcrops of Permian and older sedimentary rocks. This area was rated as having low to zero potential. The potential is downgraded because of the absence of a good reservoir sealing cover of Mesozoic rocks and because of structurally high exposures of Precambrian and Lower Paleozoic rocks.

The Southwestern Wyoming Basins province (fig. 2) extends northward into the YellowstoneAbsaroka Tertiary and Quaternary volcanic area and to the Montana-Wyoming border in Yellowstone National Park. The Gros Ventre Wilderness borders the northwest end of the Green River basin proper (fig. 1) and forms the south edge of a geologic transition area that includes the Teton uplift, Washakie uplift, and Jackson Hole (Grose, 1972). Love and others (1973) summarize the geology of the Teton region and show a threedimensional diagram of the area. Wilderness Lands on the Teton uplift have zero potential owing to the presence of extensive exposures of Precambrian igneous and metamorphic rocks and Paleozoic carbonate rocks, sandstone, and shale (Love and others, 1955; Love and others, 1973). The northernmost part of this area of zero potential does have some exposures of rocks ranging in age from Paleozoic to Quaternary, but any reservoirs in these rocks are probably flushed with freshwater.

The area rated as having low potential, located northeast of the Wilderness Lands on the Teton uplift (fig. 1), has potential for gas production from structural and stratigraphic traps in Cretaceous and Tertiary sandstone and coal beds. Most of these lands lie within the Jackson Hole coal field as shown in Hausel and others (1979) and as described by Jones (1982). Coal beds are one of the principal sources of natural gas. Love and others (1975) have studied the geology and mineral resources of the Teton Corridor which is located in the western part of the area of low potential. They noted that the potential of the Teton Cor- ridor was difficult to determine owing to laçk of drilling. However, adequate gas and oil source beds are present in Paleozoic and Cretaceous rocks (Love and others, 1975, p. A15). They also reported that a flammable gas seep is present in the Teton Corridor.

Most of the land east of and north of the area of low potential within and adjacent to the Teton Corridor is rated as having unknown potential. Much of the land rated as having unknown potential lies within Yellowstone National Park. These lands have unknown potential because they are mostly in areas where a thick cover of Tertiary and Quaternary igneous and volcaniclastic rocks and sediments obscure the underlying structure and stratigraphy of any potentially productive older rocks. Some exposures of Precambrian, Paleozoic, and Mesozoic rocks are present in the area of unknown potential. The presence of hydrocarbon source beds and reservoir rocks in most of the area having unknown potential cannot be determined. A few hot water springs in and adjacent to Yellowstone National Park have, historically, yielded small amounts of oil and (or) gas (Love and Good, 1970; Love and Good, 1982). These surface shows indicate the presence of subsurface hydrocarbon source beds that have been contacted by thermal waters and do not mean that free hydrocarbons exist in reservoirs. The areas with zero potential are about centered in Yellowstone National Park and are the approximate site of a very large caldera formed by a volcanic eruption during the Quaternary Period (Keefer, 1971, fig. 22). It is unlikely that this caldera has any oil and gas potential.

\section{WYOMING PART OF THE WYOMING-UTAH-IDAHO OVERTHRUST BELT PROVINCE}

\section{By Richard B. Powers}

The Wyoming-Utah-Idaho Overthrust Belt province straddles parts of Wyoming, Utah, and Idaho (Dolton and others, 1981) and covers a total area of 15,000 square miles $\left(39,000 \mathrm{~km}^{2}\right)$. The Wyoming part of the province is the approximate eastern half of the thrust belt. The eastern boundary of the Wyoming thrust belt (fig.1) is marked by the surface trace of the Darby-Prospect thrust plate, which separates the structurally deformed thrust belt from the Green River basin in southwestern Wyoming. 
The thrust belt is the newest oil and gas producing province in the State of Wyoming. Production was first established in 1975 at the Pineview field in adjacent Summit County, Utah, and the initial discovery in the Wyoming part of the thrust belt was in July, 1976. The petroleum geology and resource potential of this province is summarized by Monley (1971), Royse and others (1975), Powers (1977; 1982; and chapter $\mathrm{N}$, this circular).

Eighteen fields were discovered between 1975 and mid-1983 in the southern Wyoming part of the thrust belt, and four additional new-field wildcat gas discoveries were recently announced in the central part of the Wyoming thrust belt. All oil and gas production in the Wyoming thrust belt comes from anticlinal structures in the hanging walls of thrust plates. The main producing reservoirs are of Jurassic and Mississippian age from both sandstone and carbonate rocks, with additional producing reservoirs of Cretaceous, Triassic, Permian, Pennsylvanian, Devonian, and Ordovician age.

Four wilderness tracts with high oil and gas potential are located in the central and northwest parts of the thrust belt on trend with producing fields in various thrust plates. Two of the tracts are directly adjacent to new-field wildcat gas discovery wells. The same formations, similar reservoir and petroleum source rocks, and trapping structures, as well as a favorable thermal-maturation history, are interpreted to be present under these tracts in a framework similar to that in the highly productive southern part of the thrust belt.

\section{WIND RIVER BASIN PROVINCE}

The Wind River basin is a prolific producer of oil and gas from Paleozoic sandstone and carbonates, Mesozoic sandstone, and Tertiary sandstone. Benner (1972) noted that most of the oil and gas occurs in structural traps and that stratigraphic traps will become important producers in the future. This basin has very high potential for deep-basin gas production from Tertiary and Cretaceous conventional and low-permeability (unconventional) sandstone stratigraphic traps. Wilderness Lands with no potential in the westcentral, south, and southeast parts of this province are in areas where Precambrian igneous and metamorphic rocks are exposed on various uplifts flanking the basin. A small tract on the Owl Creek uplift (fig. 1) has low potential. This tract is in an area of exposed lower Paleozoic rocks (Love and others, 1955). The south flank of the Owl Creek uplift is thrust from north to south over the north edge of the Wind River basin (Gries, 1983, fig. 1). This tract has potential for oil and gas in subthrust Mesozoic and Paleozoic rocks. The best potential is for structural and stratigraphic traps in Tertiary and Cretaceous sandstones beneath the thrust. Older reservoirs could contain some hydrocarbons.

Wilderness Lands with low and medium potential are located in the northwest part of the Wind River Basin province (fig. 2). Most of these lands are in areas of Tertiary cover but a few exposures of older sedimentary rocks are present (Love and others, 1955). It is interpreted that Mesozoic and Paleozoic rocks with petroleum potential are present throughout much of the area (Ketner and others, 1966; Prostka and others, 1979).

\section{BIGHORN BASIN PROVINCE}

The Big Horn Basin province of Dolton and others (1981) shown in figure 2 covers considerably more area than the Bighorn basin structural boundaries as shown in figure 1. The name of this basin is variously spelled Big Horn and Bighorn. The generally accepted spelling is Bighorn and is used in the following discussion.

The Bighorn basin of Wyoming and adjacent Montana is one of the most prolific oil and gas basins in the Rocky Mountain region. The petroleum geology of this basin is summarized by Weldon (1972). Much of the oil and gas production comes from structural traps located around the margins of the basin. The primary producing reservoirs are Mississippian carbonate rocks, Pennsylvanian sandstone, Permian carbonate rocks, and Cretaceous sandstone. The deep part of the basin is relatively unexplored by drilling but probably has been extensively mapped by seismic methods.

Wilderness Lands on the western side of this province (fig. 2) mostly lie beneath a thick Tertiary volcanic and volcaniclastic cover (Nelson and others, 1980; Love and others, 1955). These lands have been evaluated for their relative oil and gas potential by Spencer and Dersch (1981). The potential ranges from high for lands on trend with, and near existing fields, to unknown in areas of thick Tertiary volcanic cover. The high potential areas are on trend with, and adjacent to, known oil fields that produce from Paleozoic carbonates 
and sandstone. The presence of Paleozoic and Mesozoic rocks with petroleum potential can be predicted on the basis of limited outcrops and on well control adjacent to these areas. Areas where the presence of Paleozoic and (or) Mesozoic rocks can reasonably be predicted are rated as medium potential. The low potential areas include lands where favorable source beds and reservoir rocks are probably present. The unknown potential areas are remote from well or outcrop control and the presence of sedimentary rocks with petroleum potential cannot be predicted. An area with zero potential is situated on the northwestern edge of the Wyoming part of the province. This area of zero potential has extensive exposures of Precambrian rocks.

Lands in the center of the basin have high potential for gas and some oil in Cretaceous and Tertiary sandstone stratigraphic traps. These lands are located in and near the deepest part of the Bighorn basin. The deep part of the basin is only sparsely drilled, but stratigraphic conditions here are similar to those that exist in the deep basin gas areas of the Wind River, Great Divide, Washakie, and Green River basins. It is anticipated that extensive sequences of low-permeability (unconventional) gas reservoirs will be present in Tertiary and Cretaceous sandstones in addition to conventional reservoirs. Permian carbonates and Pennsylvanian sandstone and carbonate reservoirs also have some hydrocarbon potential.

A tract with medium potential is present south of the high potential tracts. This tract has slightly lower potential because the southern part of the basin is shallower and there are less potentially oil and gas bearing Tertiary sandstones present in the area. East of this tract is a wilderness tract with medium to low potential. This tract is located in the southeast part of the basin in an area where there are many oil and gas fields. These fields are shown in VerPloeg and others (1980). The production from these fields is dominantly oil and associated gas. Permian limestones are the major producing reservoirs and they produce from both stratigraphic and structural-stratigraphic traps. Pennsylvanian sandstone also is productive in many fields. Some production has been found in Cretaceous sandstones in this part of the basin.

Wilderness Lands on the east side of the province (fig. 2) are located on the west flank of the Bighorn uplift (fig. 1). These lands have zero potential because of extensive exposures of Pre- cambrian rocks. Some tracts on the west side of this cluster of Wilderness Lands are in areas where Pennsylvanian and older rocks crop out (Lowry and others, 1976). These tracts are interpreted to have zero potential, even though sedimentary rocks are present, because of flushing by meteoric (fresh) water and lack of strong structural closures that might have the ability to facilitate the formation of hydrodynamically tilted oil accumulations.

\section{POWDER RIVER BASIN PROVINCE}

The Powder River basin (fig. 1) is a major oil producing basin with cumulative production exceeding 1 billion barrels of oil (McGregor, 1972). The basin extends northward into southeastern Montana but most of the oil and gas fields are in Wyoming. McGregor (1972) describes the general petroleum geology of the basin. Most of the oil (and associated gas) is produced from Permian and Pennsylvanian sandstone and dolomite, and Cretaceous sandstone reservoirs. In the past 20 years most of the new oil accumulations have been found in stratigraphic traps. The shallow eastern parts of the basin are extensively drilled but there is only sparse drilling in the deeper parts of the basin to the west. The tract in the geographical center of the basin, which has high potential, is in an area of sparse drilling and has high potential for oil and gas in Cretaceous sandstone stratigraphic traps. There are many oil fields (VerPloeg and others, 1980) updip to the east which produce from Cretaceous sandstone and PennsylvanianPermian sandstone and dolomite.

Lands on the east side of the Bighorn uplift (fig. 1) have low potential. These low potential tracts are in an area of exposed Precambrian igneous and metamorphic rocks and some steeply dipping Paleozoic and younger rocks. The east flank of the Bighorn uplift is interpreted to be thrust from west to east over the west side of the Powder River basin (Gries, 1983, fig. 1). Therefore, there is some potential for oil and gas in Cretaceous and older rocks beneath the overthrust. Data are not available to permit determination of the horizontal extent of overthrusting but it is probably about two to four miles (3-6 km).

Several low potential tracts on the west side of the province (fig. 2) are on the south plunge of the Bighorn uplift (fig. 1). These tracts are in an area where Mississippian carbonates and Pennsylvanian and Permian carbonates and sandstone crop 
out. There are also some local exposures of Ordovician and Cambrian rocks cropping out in areas near these tracts so the oil and gas potential is probably quite low.

\section{SUMMARY}

Of the $6,006,903$ acres included in this study for the assessment of the petroleum potential of the Wilderness Lands in Wyoming, a summary of the potential follows: high potential, 661.8 thousand acres; medium potential, 391.8 thousand acres; low potential, 723.3 thousand acres; low to zero potential, 19 thousand acres; zero potential, 1,759.3 thousand acres, and unknown potential, $2,451.8$ thousand acres. The petroleum potential by acreage of all Wilderness Land categories in the Western United States is shown in this circular by B. M. Miller in table 1, chapter P.

\section{REFERENCES CITED}

Benner, R. W., 1972, The Wind River basin, in Mallory, W. W., ed., Geologic atlas of the Rocky Mountain region: Rocky Mountain Association of Geologists, p. 273-274.

Dolton, G. L., Carlson, K. H., Charpentier, R. R., Coury, A. B., Crovelli, R. A., Frezon, S. E., Khan, A. S., Lister, J. H., McMullin, R. H., Pike, R. S., Powers, R. B., Scott, E. W., and Varnes, K. L., 1981, Estimates of undiscovered recoverable conventional resources of oil and gas in the United States: U.S. Geological Survey Circular 860, 87 p.

Gries, Robbie, 1983, Oil and gas prospecting beneath Precambrian of foreland thrust plates in Rocky Mountains: American Association of Petroleum Geologists Bulletin, v. 67, no. 1, p. 1-28.

Grose, L. T., 1972, Tectonics, in Mallory, W. W., ed., Geologic atlas of the Rocky Mountain Region: Rocky Mountain Association of Geologists, p. 35-44.

Hausel, W. D., Glass, G. B., Langeson, D. R., VerPloeg, A. J., and DeBruin, R. H., 1979, Wyoming mines and minerals: Wyoming Geological Survey, scale 1:500,000.

Jones, R. W., 1982, The Jackson Hole coal field, in Geology of Yellowstone Park area, 33rd Annual Field Conference Guidebook: Wyoming Geological Association, p. 315-321.

Keefer, W. R., 1971, The geologic story of Yellowstone National Park: U.S. Geological Survey Bulletin 1347, 92 p.

Ketner, K. B., Keefer, W. R., Fisher, F. S., Smith, D. L., and Raabe, R. G., 1966, Mineral resources of the Stratified Primitive Area, Wyoming: U.S. Geological Survey Bulletin 1230-E, 56 p.

Love, J. D., Antweiler, J. C., and Williams, F. E., 1975, Mineral resources of the Teton Corridor, Teton County, Wyoming: U.S. Geological Survey Bulletin 1397-A, 51 p.

Love, J. D., and Good, J. M., 1970, Hydrocarbons in thermal areas, northwestern Wyoming: U.S. Geological Survey Professional Paper 644-B, 23 p.
1982, Hydrocarbons in thermal areas, northwestern Wyoming, in Geology of Yellowstone Park area, 33rd Annual Field Conference: Wyoming Geological Association, p. 265-288.

Love, J. D., Reed, J. C., Jr., Christiansen, R. L., and Stacy, J. R., 1973, Geologic block diagram and tectonic history of the Teton region, Wyoming-Idaho: U.S. Geological Survey Miscellaneous Geologic Investigations Map I-730.

Love, J. D., Weitz, J. L., and Hose, R. K., 1955, Geologic map of Wyoming: U.S. Geological Survey, scale 1:500,000.

Lowery, M. E. Lowham, H. W., and Lines, G. C., 1976, Water resources of the Bighorn basin, northwestern Wyoming: U.S. Geological Survey Hydrologic Investigations Atlas HA-512, 4 sheets.

Mallory, W. W., ed., 1972, Geologic atlas of the Rocky Mountain region: Rocky Mountain Association of Geologists, 331 p.

McGregor, A. A., 1972, The Powder River basin, in Mallory, W. W., ed., Geologic atlas of the Rocky Mountain region: Rocky Mountain Association of Geologists, p. 268-270.

Monley, L. E., 1971, Petroleum potential of the Idaho-Wyoming Overthrust Belt, in Future petroleum provinces of the United States - their geology and potential: American Association of Petroleum Geologists Memoir 15, v. 1, p. 509 537.

Nelson, W. H., Prostka, H. J., and Williams, F. E., 1980, Geology and mineral resources of the North Absaroka Wilderness and vicinity, Park County, Wyoming: U.S. Geological Survey Bulletin, 1447, 101 p.

Powers, R. B., 1977, Assessment of oil and gas resources in the Idaho-Wyoming Thrust Belt, in Rocky Mountain thrust belt geology and resources, 29th Annual Field Conference Guidebook: Wyoming Geological Association, p. $629-638$.

, ed., 1982, Geologic studies of the Cordilleran Thrust Belt: Rocky Mountain Association of Geologists, 976 p.

Prostka, H. J., Antweiler, J. C., and Bieniewski, C. L., 1979, Mineral resources of the Du Noir Addition, Washakie Wilderness, Fremont County, Wyoming: U.S. Geological Survey Bulletin 1472, $35 \mathrm{p}$.

Royse, Frank, Jr., Warner, M. A., and Reese, D. L., 1975, Thrust belt structural geometry and related stratigraphic problems, Wyoming-Idaho-Northern Utah, in Bolyard, D. W., ed., Symposium on deep drilling frontiers in the central Rocky Mountains: Rocky Mountain Association of Geologists, p. 41-54.

Simons, F. S., Love, J. D., Keefer, W. R., Harwood, D. S., and Bieniewski, C. L., 1980, Mineral Resources of the Gros Ventre Wilderness Study Area, Teton and Sublette Counties, Wyoming: U.S. Geological Survey Open-File Report 80-510, $94 \mathrm{p}$.

Skeeters, W. W., and Hale, L. A., 1972, Southern Wyoming, in Mallory, W. W., ed., Geologic atlas of the rocky Mountain region: Rocky Mountain Association of Geologists, p. 274-276.

Spencer, C. W., and Dersch, J. S., 1981, Map showing evaluation of oil and gas potential of the Shoshone National Forest, Wyoming: U.S. Geological Survey Open-File Report $81-667$, scale $1: 500,000$.

U.S. Bureau of Land Management, 1981, State of Wyoming wilderness status map: U.S. Bureau of Land Management, scale 1:1,000,000. 
VerPloeg, A. J., DeBruin, R. H., and Langeson, D. R., 1980, Oil and gas map of Wyoming: Geological Survey of Wyoming, Map Series 6, scale 1:500,000.

Weldon, J. P., 1972, The Big Horn basin, in Mallory, W. W., ed., Geologic atlas of the Rocky Mountain region: Rocky
Mountain Association of Geologists, p. 270-272. .

Wyoming Oil and Gas Conservation Commission, 1981, Wyoming oil and gas statistics, 1981: Wyoming Oil and Gas Conservation Commission, $123 \mathrm{p}$. 